\title{
PENGEMBANGAN BAHAN AJAR DI PERGURUAN TINGGI
}

\author{
Wahyu Sri Ambar Arum
}

\begin{abstract}
In competency based learning, instructional materials play an important role in helping students achieving a set of competencies. Therefore the instructional materials should be prepared as good as possible. this article will discuss the role and definition of instructional materials, the principles and the steps of instructional material selection, the sources of instructional materials, the scope and the sequence of instructional materials, the strategies of using it, and finally the forms of instructional materials.
\end{abstract}

Kata kunci: bahan ajar, materi pembelajaran, standarkompetensi

\section{PENDAHULUAN}

Bahan ajar dapat digunakan untuk membantu dosen dan mahasiswa dalam perkuliahan, sehingga dosen tidak perlu terlalu banyak menyajikan materi di kelas dan mempunyai lebih banyak waktu untuk memberi bimbingan kepada mahasiswa

Masalah penting yang sering dihadapi dosen dalam kegiatan pembelajaran adalah memilih atau menentukan materi pembelajaran atau bahan ajar yang tepat dalam rangka membantu mahasiswa mencapai kompetensi. Hal ini disebabkan oleh kenyataan bahwa dalam kurikulum atau silabus, materi bahan ajar hanya dituliskan secara garis besar dalam bentuk "materi pokok". Menjadi tugas dosen untuk menjabarkan materi pokok tersebut sehingga menjadi bahan ajar yang lengkap. Selain itu, bagaimana cara memanfaatkan bahan ajar juga merupakan masalah. Pemanfaatan yang dimaksud adalah bagaimana cara mengajarkannya ditinjau dari pihak dosen dan cara mempelajarinya ditinjau dari pihak mahasiswa.

Berkenaan dengan pemilihan bahan ajar, secara umum masalah yang sering dihadapi meliputi cara penentuan jenis materi, kedalaman, ruang lingkup, urutan penyajian, perlakuan (treatment) terhadap materi pembelajaran, serta memilih sumber di mana bahan ajar itu didapatkan. Ada kecenderungan sumber bahan ajar dititikberatkan pada buku. Padahal banyak sumber bahan ajar selain buku yang dapat digunakan. Bukupun tidak harus satu macam dan tidak harus sering berganti seperti terjadi selama ini. Berbagai buku dapat dipilih sebagai sumber bahan ajar.

Termasuk masalah yang sering dihadapi dosen berkenaan dengan bahan ajar adalah dosen memberikan bahan ajar atau materi pembelajaran terlalu luas atau terlalu sedikit, terlalu mendalam atau terlalu dangkal, urutan penyajian yang tidak tepat, dan jenis materi bahan ajar yang tidak sesuai dengan kompetensi yang ingin dicapai oleh mahasiswa.

Sehubungan dengan itu, maka penulis memberikan gambaran tentang pemilihan dan pemanfaatan bahan ajar untuk membantu dosen agar mampu memilih materi pembelajaran atau bahan ajar dan memanfaatkannya dengan tepat, konsep dan prinsip pemilihan materi pembelajaran, penentuan cakupan, urutan, kriteria dan langkah-langkah pemilihan, perlakuan/pemanfaatan serta sumber materi pembelajaran.

\section{PEMBAHASAN}

Pemilihan Bahan Ajar dalam Pembelajaran Berbasis Kompetensi (PBK)

Pembelajaran berbasis kompetensi didasarkan atas pokok-pokok pikiran bahwa apa yang ingin dicapai oleh mahasiswa melalui kegiatan pembelajaran harus dirumuskan dengan jelas. Perumusan dimaksud diwujudkan dalam bentuk standar kompetensi yang diharapkan dikuasai oleh mahasiswa. Standar kompetensi meliputi standar materi atau standar isi (content standard) dan standar pencapaian (performance standard). Standar materi berisikan jenis, kedalaman, dan ruang lingkup materi pembelajaran yang harus dikuasi mahasiswa, sedangkan standar penampilan berisikan tingkat penguasaan yang harus ditampilkan mahasiswa. Tingkat penguasaan itu misalnya harus 100\% dikuasai atau boleh kurang dari 100\%. Sesuai dengan pokokpokok pikiran tersebut, masalah materi pembelajaran 
memegang peranan penting dalam rangka membantu mahasiswa mencapai standar kompetensi.

Kapankah materi pembelajaran atau bahan ajar ditentukan atau dipilih? Dalam rangka pelaksanaan pembelajaran, termasuk pembelajaran berbasis kompetensi, bahan ajar dipilih setelah identitas mata pelajaran, standar kompetensi, dan kompetensi dasar ditentukan. Seperti diketahui, langkah-langkah pengembangan pembelajaran sesuai KBK antara lain pertama-tama menentukan identitas mata pelajaran. Setelah itu menentukan standar kompetensi, kompetensi dasar, materi pembelajaran, strategi pembelajaran/pengalaman belajar, indikator pencapaian, dst. Setelah pokok-pokok materi pembelajaran ditentukan, materi tersebut kemudian diuraikan. Uraian materi pembelajaran dapat berisikan butir-butir materi penting (key concepts) yang harus dipelajari mahasiswa atau dalam bentuk uraian secara lengkap seperti yang terdapat dalam buku-buku pelajaran.

Bahan ajar merupakan salah satu komponen sistem pembelajaran yang memegang peranan penting dalam membantu mahasiswa mencapai standar kompetensi dan kompetensi dasar. Secara garis besar, bahan ajar atau materi pembelajaran berisikan pengetahuan, keterampilan, dan sikap atau nilai yang harus dipelajari mahasiswa.

Materi pembelajaran perlu dipilih dengan tepat agar seoptimal mungkin membantu mahasiswa dalam mencapai standar kompetensi dan kompetensi dasar. Masalah-masalah yang timbul berkenaan dengan pemilihan materi pembelajaran menyangkut jenis, cakupan, urutan, perlakuan (treatment) terhadap materi pembelajaran dan sumber bahan ajar. Jenis materi pembelajaran perlu diidentifikasi atau ditentukan dengan tepat karena setiap jenis materi pembelajaran memerlukan strategi, media, dan cara mengevaluasi yang berbeda-beda. Cakupan atau ruang lingkup serta kedalaman materi pembelajaran perlu diperhatikan agar tidak kurang dan tidak lebih. Urutan (sequence) perlu diperhatikan agar pembelajaran menjadi runtut. Perlakuan (cara mengajarkan/ menyampaikan dan mempelajari) perlu dipilih setepat-tepatnya agar tidak salah mengajarkan atau mempelajarinya (misalnya perlu kejelasan apakah suatu materi harus dihafalkan, dipahami atau diaplikasikan).

\section{Pengertian Bahan Ajar (Materi Pembelajaran)}

Bahan ajar atau materi pembelajaran (instructional materials) adalah bahan-bahan atau materi perkuliahan. Bahan ajar bukan buku teks. Bahan ajar ditulis dan dirancang untuk digunakan mahasiswa, berfokus pada pemberian kesempatan mahasiswa untuk berlatih. Secara garis besar bahan ajar terdiri dari pengetahuan, keterampilan, dan sikap yang harus dipelajari mahasiswa dalam rangka mencapai standar kompetensi yang telah ditentukan. Secara terperinci, jenis-jenis materi pembelajaran terdiri dari pengetahuan (fakta, konsep, prinsip, prosedur), keterampilan, dan sikap atau nilai.

Termasuk jenis materi fakta adalah nama-nama obyek, peristiwa sejarah, lambang, nama tempat, nama orang, dsb. Termasuk materi prinsip adalah dalil, rumus, adagium, postulat atau hubungan antar konsep yang menggambarkan "jika... maka...". Materi jenis prosedur adalah materi yang berkenaan dengan langkah-langkah secara sistematis atau berurutan dalam mengerjakan suatu tugas. Misalnya langkahlangkah mengoperasikan peralatan mikroskup, cara menyetel televisi. Materi jenis sikap (afektif) adalah materi yang berkenaan dengan sikap atau nilai, misalnya nilai kejujuran, kasih sayang, tolongmenolong, semangat dan minat belajar, semangat bekerja, dsb.

Ditinjau dari pihak dosen, materi pembelajaran itu harus diajarkan atau disampaikan dalam kegiatan pembelajaran. Ditinjau dari pihak mahasiswa bahan ajar itu harus dipelajari mahasiswa dalam rangka mencapai standar kompetensi dan kompetensi dasar yang akan dinilai dengan menggunakan instrumen penilaian yang disusun berdasar indikator pencapaian belajar.

\section{Prinsip-prinsip Pemilihan Bahan Ajar}

Ada beberapa prinsip yang perlu diperhatikan dalam penyusunan bahan ajar atau materi pembelajaran. Prinsip-prinsip dalam pemilihan materi pembelajaran meliputi prinsip relevansi, konsistensi, dan kecukupan.

Prinsip relevansi artinya keterkaitan. Materi pembelajaran hendaknya relevan atau ada kaitan atau ada hubungannya dengan pencapaian standar kompetensi dan kompetensi dasar. Misalnya, jika kompetensi yang diharapkan dikuasai mahasiswa berupa menghafal fakta, maka materi pembelajaran yang diajarkan harus berupa fakta.

Prinsip konsistensi artinya keajegan. Jika kompetensi dasar yang harus dikuasai mahasiswa empat macam, maka bahan ajar yang harus diajarkan juga harus meliputi empat macam.

Prinsip kecukupan artinya materi yang diajarkan hendaknya cukup memadai dalam membantu mahasiswa menguasai kompetensi dasar 
yang diajarkan. Materi tidak boleh terlalu sedikit, dan tidak boleh terlalu banyak. Jika terlalu sedikit akan kurang membantu mencapai standar kompetensi dan kompetensi dasar. Sebaliknya, jika terlalu banyak akan membuang-buang waktu dan tenaga yang tidak perlu untuk mempelajarinya.

\section{Langkah-langkah Pemilihan Bahan Ajar}

Sebelum melaksanakan pemilihan bahan ajar, terlebih dahulu perlu diketahui kriteria pemilihan bahan ajar. Kriteria pokok pemilihan bahan ajar atau materi pembelajaran adalah standar kompetensi dan kompetensi dasar. Hal ini berarti bahwa materi pembelajaran yang dipilih untuk diajarkan oleh dosen di satu pihak dan harus dipelajari mahasiswa di lain pihak hendaknya berisikan materi atau bahan ajar yang benar-benar menunjang tercapainya standar kompetensi dan kompetensi dasar. Dengan kata lain, pemilihan bahan ajar haruslah mengacu atau merujuk pada standar kompetensi.

Setelah diketahui kriteria pemilihan bahan ajar, sampailah kita pada langkah-langkah pemilihan bahan ajar. Secara garis besar langkah-langkah pemilihan bahan ajar meliputi pertama-tama mengidentifikasi aspek-aspek yang terdapat dalam standar kompetensi dan kompetensi dasar yang menjadi acuan atau rujukan pemilihan bahan ajar. Langkah berikutnya adalah mengidentifikasi jenisjenis materi bahan ajar. Langkah ketiga memilih bahan ajar yang sesuai atau relevan dengan standar kompetensi dan kompetensi dasar yang telah teridentifikasi tadi. Terakhir adalah memilih sumber bahan ajar.

Secara lengkap, langkah-langkah pemilihan bahan ajar dapat dijelaskan sebagai berikut.

A. Mengidentifikasi aspek-aspek yang terdapat dalam standar kompetensi dan kompetensi dasar.

1. Sebelum menentukan materi pembelajaran terlebih dahulu perlu diidentifikasi aspek-aspek standar kompetensi dan kompetensi dasar yang harus dipelajari atau dikuasai mahasiswa. Aspek tersebut perlu ditentukan, karena setiap aspek standar kompetensi dan kompetensi dasar memerlukan jenis materi yang berbeda-beda dalam kegiatan pembelajaran.

2. Setiap aspek standar kompetensi tersebut memerlukan materi pembelajaran atau bahan ajar yang berbeda-beda untuk membantu pencapaiannya.

B. Identifikasi jenis-jenis materi pembelajaran. Sejalan dengan berbagai jenis aspek standar kompetensi, materi pembelajaran juga dapat dibedakan menjadi jenis materi aspek kognitif, afektif, dan psikomotorik. Materi pembelajaran aspek kognitif secara terperinci dapat dibagi menjadi empat jenis, yaitu: fakta, konsep, prinsip, dan prosedur (Reigeluth, 1987).

1. Materi jenis fakta adalah materi berupa namanama objek, nama tempat, nama orang, lambang, peristiwa sejarah, nama bagian atau komponen suatu benda, dan lain sebagainya.

2. Materi konsep berupa pengertian, definisi, hakekat, inti isi.

3. Materi jenis prinsip berupa dalil, rumus, postulat adagium, paradigma, teorema.

4. Materi jenis prosedur berupa langkah-langkah mengerjakan sesuatu secara urut, misalnya langkah-langkah menelpon, cara-cara pembuatan telur asin atau cara-cara pembuatan bel listrik.

5. Materi pembelajaran aspek afektif meliputi: pemberian respon, penerimaan (apresisasi), internalisasi, dan penilaian.

6. Materi pembelajaran aspek motorik terdiri dari gerakan awal, semi rutin, dan rutin.

C. Memilih jenis materi yang sesuai dengan standar kompetensi dan kompetensi dasar.

Pilih jenis materi yang sesuai dengan standar kompetensi yang telah ditentukan. Perhatikan pula jumlah atau ruang lingkup yang cukup memadai sehingga mempermudah mahasiswa dalam mencapai standar kompetensi.

Berpijak dari aspek-aspek standar kompetensi dan kompetensi dasar yang telah diidentifikasi, langkah selanjutnya adalah memilih jenis materi yang sesuai dengan aspek-aspek yang terdapat dalam standar kompetensi dan kompetensi dasar tersebut. Materi yang akan diajarkan perlu diidentifikasi apakah termasuk jenis fakta, konsep, prinsip, prosedur, afektif, atau gabungan lebih daripada satu jenis materi. Dengan mengidentifikasi jenis-jenis materi yang akan diajarkan, maka dosen akan mendapatkan kemudahan dalam cara mengajarkannya.

Setelah jenis materi pembelajaran teridentifikasi, langkah berikutnya adalah memilih jenis materi tersebut yang sesuai dengan standar kompetensi atau kompetensi dasar yang harus dikuasai mahasiswa. Identifikasi jenis materi pembelajaran juga penting untuk keperluan mengajarkannya. Sebab, setiap jenis materi pembelajaran memerlukan strategi pembelajaran atau metode, media, dan sistem evaluasi/penilaian 
yang berbeda-beda. Misalnya metode mengajarkan materi fakta atau hafalan adalah dengan menggunakan "jembatan keledai", "jembatan ingatan" (mnemonics), sedangkan metode untuk mengajarkan prosedur adalah "demonstrasi".

Cara yang paling mudah untuk menentukan jenis materi pembelajaran yang akan diajarkan adalah dengan jalan mengajukan pertanyaan tentang kompetensi dasar yang harus dikuasai mahasiswa.

Dengan mengacu pada kompetensi dasar, kita akan mengetahui apakah materi yang harus kita ajarkan berupa fakta, konsep, prinsip, prosedur, aspek sikap, atau psikomotorik. Pertanyaanpertanyaan penuntun untuk mengidentifikasi jenis materi pembelajaran adalah sebagai berikut.

1. Apakah kompetensi dasar yang harus dikuasai mahasiswa berupa mengingat nama suatu objek, simbul atau suatu peristiwa? Kalau jawabannya "ya" maka materi pembelajaran yang harus diajarkan adalah "fakta".

Contoh:: Nama-nama ibukota Negara, peristiwa sejarah, nama-nama organ tubuh manusia.

2. Apakah kompetensi dasar yang harus dikuasai mahasiswa berupa kemampuan untuk menyatakan suatu definisi, menuliskan ciri khas sesuatu, mengklasifikasikan atau mengelompokkan beberapa contoh objek sesuai dengan suatu definisi ? Kalau jawabannya "ya" berarti materi yang harus diajarkan adalah "konsep".

Contoh: Seorang dosen menunjukkan beberapa tumbuh-tumbuhan kemudian mahasiswa diminta untuk mengklasifikasikan atau mengelompokkan mana yang termasuk tumbuhan berakar serabut dan mana yang berakar tunggang.

3. Apakah kompetensi dasar yang harus dikuasai mahasiswa berupa menjelaskan atau melakukan langkah-langkah atau prosedur secara urut atau membuat sesuatu? Bila "ya" maka materi yang harus diajarkan adalah "prosedur".

Contoh : Langkah-langkah mengatasi permasalahan dalam mewujudkan masyarakat demokrasi; langkah-langkah membuat magnet buatan; cara-cara membuat sabun mandi, cara membaca sanjak, cara mengoperasikan komputer, dsb.

4. Apakah kompetensi dasar yang harus dikuasai mahasiswa berupa menentukan hubungan antara beberapa konsep atau menerapkan hubungan antara berbagai macam konsep? Bila jawabannya "ya", berarti materi pembelajaran yang harus diajarkan termasuk dalam kategori "prinsip".

Contoh: Ali memilih mentaati tata tertib kuliah meskipun terlambat masuk kuliah setelah diajarkan pentingnya mentaati tata tertib kuliah

5. Apakah kompetensi dasar yang harus dikuasai mahasiswa berupa melakukan perbuatan secara fisik? Jika jawabannya "Ya", maka materi pembelajaran yang harus diajarkan adalah aspek motorik.

Contoh: Dalam pelajaran lompat tinggi, mahasiswa diharapkan mampu melompati mistar 125 centimeter. Materi pembelajaran yang harus diajarkan adalah teknik lompat tinggi.

\section{Memilih Sumber Bahan Ajar}

Setelah jenis materi ditentukan langkah berikutnya adalah menentukan sumber bahan ajar. Materi pembelajaran atau bahan ajar dapat kita temukan dari berbagai sumber seperti buku pelajaran, majalah, jurnal, koran, internet, media audiovisual, dsb.

\section{Penentuan Cakupan Cakupan dan Urutan Bahan Ajar}

Masalah cakupan atau ruang lingkup, kedalaman, dan urutan penyampaian materi pembelajaran penting diperhatikan. Ketepatan dalam menentukan cakupan, ruang lingkup, dan kedalaman materi pembelajaran akan menghindarkan dosen dari mengajarkan terlalu sedikit atau terlalu banyak, terlalu dangkal atau terlalu mendalam. Ketepatan urutan penyajian (sequencing) akan memudahkan bagi mahasiswa mempelajari materi pembelajaran.

\section{A. Penentuan Cakupan Bahan Ajar}

Dalam menentukan cakupan atau ruang lingkup materi pembelajaran harus diperhatikan apakah materinya berupa aspek kognitif (fakta, konsep, prinsip, prosedur) aspek afektif, ataukah aspek psikomotorik, sebab nantinya jika sudah dibawa ke kelas maka masing-masing jenis materi tersebut memerlukan strategi dan media pembelajaran yang berbeda-beda.

Selain memperhatikan jenis materi pembelajaran juga harus memperhatikan prinsipprinsip yang perlu digunakan dalam menentukan cakupan materi pembelajaran yang menyangkut keluasan dan kedalaman materinya. Keluasan 
cakupan materi berarti menggambarkan berapa banyak materi-materi yang dimasukkan ke dalam suatu materi pembelajaran, sedangkan kedalaman materi menyangkut seberapa detail konsep-konsep yang terkandung di dalamnya harus dipelajari/ dikuasai oleh mahasiswa. Di perguruan tinggi, namun keluasan dan kedalaman pada setiap jenjang pendidikan tersebut akan berbeda-beda. Semakin tinggi jenjang pendidikan akan semakin luas cakupan aspek proses fotosintesis yang dipelajari dan semakin detail pula setiap aspek yang dipelajari. Prinsip berikutnya adalah prinsip kecukupan (adequacy). Kecukupan (adequacy) atau memadainya cakupan materi juga perlu diperhatikan dalam pengertian. Cukup tidaknya aspek materi dari suatu materi pembelajaran akan sangat membantu tercapainya penguasaan kompetensi dasar yang telah ditentukan. Misalnya, jika suatu pelajaran dimaksudkan untuk memberikan kemampuan kepada mahasiswa di bidang jual beli, maka uraian materinya mencakup: (1) penguasaan atas konsep pembelian, penjualan, laba, dan rugi; (2) rumus menghitung laba dan rugi jika diketahui pembelian dan penjualan; dan (3) penerapan/aplikasi rumus menghitung laba dan rugi.

Cakupan atau ruang lingkup materi perlu ditentukan untuk mengetahui apakah materi yang harus dipelajari oleh mahasiswa terlalu banyak, terlalu sedikit, atau telah memadai sehingga sesuai dengan kompetensi dasar yang ingin dicapai. Misalnya dalam mata pelajaran Bahasa Indonesia, salah satu kompetensi dasar yang diharapkan dimiliki oleh mahasiswa adalah "Membuat Surat Dinas". Setelah diidentifikasi, ternyata materi pembelajaran untuk mencapai kemampuan Membuat Surat Dinas tersebut termasuk jenis prosedur. Jika kita analisis, secara garis besar cakupan materi yang harus dipelajari mahasiswa agar mampu membuat surat dinas meliputi: (1) Pembuatan draft atau konsep surat; (2) Pengetikan surat; (3) Pemberian nomor agenda; dan (4) Pengiriman. Setiap jenis dari keempat materi tersebut masih dapat diperinci lebih lanjut.

\section{B. Penentuan Urutan Bahan Ajar}

Urutan penyajian (sequencing) bahan ajar sangat penting untuk menentukan urutan mempelajari atau mengajarkannya. Tanpa urutan yang tepat, jika di antara beberapa materi pembelajaran mempunyai hubungan yang bersifat prasyarat (prerequisite) akan menyulitkan mahasiswa dalam mempelajarinya.

Materi pembelajaran yang sudah ditentukan ruang lingkup serta kedalamannya dapat diurutkan melalui dua pendekatan pokok sebagai berikut.

1. Pendekatan prosedural.

Urutan materi pembelajaran secara prosedural menggambarkan langkah-langkah secara urut sesuai dengan langkah-langkah melaksanakan suatu tugas. Misalnya langkah-langkah menelpon dan langkah-langkah mengoperasikan peralatan kamera video.

2. Pendekatan hierarkis

Urutan materi pembelajaran secara hierarkis menggambarkan urutan yang bersifat berjenjang dari bawah ke atas atau dari atas ke bawah. Materi sebelumnya harus dipelajari dahulu sebagai prasyarat untuk mempelajari materi berikutnya.

Contoh: Urutan Hierarkis (berjenjang)

Soal cerita tentang perhitungan laba rugi dalam jual beli agar mahasiswa mampu menghitung laba atau rugi dalam jual beli (penerapan rumus/dalil), mahasiswa terlebih dahulu harus mempelajari konsep/pengertian laba, rugi, penjualan, pembelian, modal dasar (penguasaan konsep). Setelah itu mahasiswa perlu mempelajari rumus/dalil menghitung laba, dan rugi (penguasaan dalil). Selanjutnya mahasiswa menerapkan dalil atau prinsip jual beli (penguasaan penerapan dalil).

\section{Sumber Bahan Ajar}

Sumber bahan ajar merupakan tempat di mana bahan ajar dapat diperoleh. Dalam mencari sumber bahan ajar, mahasiswa dapat dilibatkan untuk mencarinya. Misalnya, mahasiswa diberi tugas untuk mencari koran, majalah, hasil penelitian, dsb. Hal ini sesuai dengan prinsip pembelajaran mahasiswa aktif. Berbagai sumber dapat kita gunakan untuk mendapatkan materi pembelajaran dari setiap standar kompetensi dan kompetensi dasar. Sumber-sumber yang dimaksud adalah sebagai berikut.

1. Buku teks.

Buku teks yang diterbitkan oleh berbagai penerbit dapat dipilih untuk digunakan sebagai sumber bahan ajar. Buku teks yang digunakan sebagai sumber bahan ajar untuk suatu jenis mata pelajaran tidak harus hanya satu jenis, apa lagi hanya berasal dari satu pengarang atau 
penerbit. Gunakan sebanyak mungkin buku teks agar dapat diperoleh wawasan yang luas.

2. Laporan hasil penelitian.

Laporan hasil penelitian yang diterbitkan oleh lembaga penelitian atau oleh para peneliti sangat berguna untuk mendapatkan sumber bahan ajar yang aktual atau mutakhir.

3. Jurnal (penerbitan hasil penelitian dan pemikiran ilmiah).

Penerbitan berkala yang berisikan hasil penelitian atau hasil pemikiran sangat bermanfaat untuk digunakan sebagai sumber bahan ajar. Jurnal-jurnal tersebut berisikan berbagai hasil penelitian dan pendapat dari para ahli di bidangnya masing-masing yang telah dikaji kebenarannya.

4. Pakar bidang studi.

Pakar atau ahli bidang studi penting digunakan sebagai sumber bahan ajar. Pakar tadi dapat dimintai konsultasi mengenai kebenaran materi atau bahan ajar, ruang lingkup, kedalaman, urutan, dsb.

5. Profesional.

Kalangan profesional adalah orang-orang yang bekerja pada bidang tertentu. Kalangan perbankan misalnya tentu ahli di bidang ekonomi dan keuangan. Sehubungan dengan itu bahan ajar yang berkenaan dengan ekonomi dan keuangan dapat ditanyakan pada orangorang yang bekerja di perbankan.

6. Buku kurikulum.

Buku kurikulum penting untuk digunakan sebagai sumber bahan ajar. Karena berdasarkan kurikulum itulah standar kompetensi, kompetensi dasar, dan materi bahan dapat ditemukan. Hanya saja materi yang tercantum dalam kurikulum hanya berisikan pokok-pokok materi. Dosenlah yang harus menjabarkan materi pokok menjadi bahan ajar yang terperinci.

7. Penerbitan berkala seperti harian, mingguan, dan bulanan.

Penerbitan berkala seperti koran banyak berisikan informasi yang berkenaan dengan bahan ajar suatu mata pelajaran. Penyajian dalam koran-koran atau mingguan menggunakan bahasa populer yang mudah dipahami. Karena itu baik sekali apabila penerbitan tersebut digunakan sebagai sumber bahan ajar.

8. Internet.

Bahan ajar dapat pula diperoleh melalui jaringan internet. Di internet kita dapat memperoleh segala macam sumber bahan ajar. Bahkan satuan pelajaran harian untuk berbagai mata pelajaran dapat kita peroleh melalui internet. Bahan tersebut dapat dicetak atau dikopi.

9. Media audiovisual (TV, Video, VCD, kaset audio).

Berbagai jenis media audiovisual berisikan pula bahan ajar untuk berbagai jenis mata pelajaran. Kita dapat mempelajari kehidupan di gunung berapi, di laut, dan di hutan belantara melalui siaran televisi.

10. Lingkungan (alam, sosial, seni budaya, teknik, industri, dan ekonomi).

Berbagai lingkungan seperti lingkungan alam, sosial, seni budaya, teknik, industri, dan lingkungan ekonomi dapat digunakan sebagai sumber bahan ajar. Untuk mempelajari abrasi atau penggerusan pantai, jenis pasir, dan gelombang pasang misalnya kita dapat menggunakan lingkungan alam berupa pantai sebagai sumber.

Perlu diingat, dalam menyusun rencana pembelajaran berbasis kompetensi, buku-buku atau terbitan tersebut hanya merupakan bahan rujukan. Artinya, tidaklah tepat jika hanya menggantungkan pada buku teks sebagai satu-satunya sumber bahan ajar. Tidak tepat pula tindakan mengganti buku pelajaran pada setiap pergantian semester atau pergantian tahun. Buku-buku pelajaran atau buku teks yang ada perlu dipelajari untuk dipilih dan digunakan sebagai sumber yang relevan dengan materi yang telah dipilih untuk diajarkan.

Mengajar bukanlah menyelesaikan satu buku, tetapi membantu mahasiswa mencapai kompetensi. Karena itu, hendaknya dosen menggunakan banyak sumber materi. Bagi dosen, sumber utama untuk mendapatkan materi pembelajaran adalah buku teks dan buku penunjang yang lain.

\section{Langkah-langkah Pemanfaatan Bahan Ajar}

A. Strategi penyampaian bahan ajar oleh Dosen.

Strategi penyampaian bahan ajar oleh Dosen adalah sebagai berikut.

1. Strategi urutan penyampaian simultan. Jika dosen harus menyampaikan materi pembelajaran lebih dari satu, maka menurut strategi urutan penyampaian simultan, materi secara keseluruhan disajikan secara serentak, baru kemudian diperdalam satu demi satu (Metode global).

2. Strategi urutan penyampaian suksesif. 
Jika dosen harus manyampaikan materi pembelajaran lebih dari satu, maka menurut strategi urutan panyampaian suksesif, sebuah materi satu demi satu disajikan secara mendalam baru kemudian secara berurutan menyajikan materi berikutnya secara mendalam pula.

3. Strategi penyampaian fakta.

Jika dosen harus manyajikan materi pembelajaran termasuk jenis fakta (nama-nama benda, nama tempat, peristiwa sejarah, nama orang, nama lambang atau simbol, dsb). Strategi yang tepat untuk mengajarkan materi tersebut adalah sebagai berikut.

a. Sajikan materi fakta dengan lisan, tulisan atau gambar.

b. Berikan bantuan kepada mahasiswa untuk menghafal. Bantuan diberikan dalam bentuk penyampaian secara bermakna, menggunakan jembatan ingatan, jembatan keledai, atau mnemonics, asosiasi berpasangan, dsb. Bantuan penyampaian materi fakta secara bermakna, misalnya menggunakan cara berpikir tertentu untuk membantu menghafal. Sebagai contoh, untuk menghafal jenis-jenis sumber belajar digunakan cara berpikir seperti; apa, oleh siapa, dengan menggunakan bahan, alat, teknik, dan lingkungan seperti apa? Berdasarkan kerangka berpikir tersebut, jenis-jenis sumber belajar diklasifikasikan menjadi; pesan, orang, bahan, alat, teknik, dan lingkungan. Bantuan mengingat-ingat jenis-jenis sumber belajar tersebut menggunakan jembatan keledai, jembatan ingatan (mnemonics) menjadi POBATEL (pesan, orang, bahan, alat, teknik, dan lingkungan).

Bantuan menghafal berupa asosiasi berpasangan (pair association) misalnya untuk mengingat-ingat di mana letak stalakmit dan stalaktit pada pelajaran sains. Apakah stalaktit di atas atau di bawah? Untuk menjawab pertanyaan tersebut, pasangkan huruf $\mathrm{T}$ pada atas, dengan $\mathrm{T}$ pada tit-nya stalaktit. Jadi stalaktit terletak di atas, sedangkan stalakmit terletak di bawah.

4. Strategi penyampaian konsep

Materi pembelajaran jenis konsep adalah materi berupa definisi atau pengertian. Tujuan mempelajari konsep adalah agar mahasiswa paham, dapat menunjukkan ciri-ciri, unsur, membedakan, membandingkan, menggeneralisasi, dsb.

Langkah-langkah mengajarkan konsep antara lain: pertama sajikan konsep, kedua berikan bantuan (berupa inti isi, ciri-ciri pokok, contoh dan bukan contoh), ketiga berikan latihan (exercise) misalnya, berupa tugas untuk mencari contoh lain, keempat berikan umpan balik, dan kelima berikan tes.

5. Strategi penyampaian materi pembelajaran prinsip.

Termasuk materi pembelajaran jenis prinsip adalah dalil, rumus, hukum (law), postulat, teorema, dsb.

Langkah-langkah mengajarkan atau menyampaikan materi pembelajaran jenis prinsip antara lain :

a) sajikan prinsip;

b) berikan bantuan berupa contoh penerapan prinsip;

c) berikan soal-soal latihan;

d) berikan umpan balik; dan

e) berikan tes.

6. Strategi penyampaian prosedur.

Tujuan mempelajari prosedur adalah agar mahasiswa dapat melakukan atau mempraktekkan prosedur tersebut, bukan sekedar paham atau hafal.Termasuk materi pembelajaran jenis prosedur adalah langkah-langkah mengerjakan suatu tugas secara urut. Misalnya langkahlangkah menyetel televisi.

Langkah-langkah mengajarkan prosedur meliputi:

a. menyajikan prosedur;

b. pemberian bantuan dengan jalan mendemonstrasikan bagaimana cara melaksanakan prosedur;

c. memberikan latihan (praktek);

d. memberikan umpan balik; dan

e. memberikan tes.

Contoh: Prosedur menelpon di telpon umum koin.

Langkah-langkah mengajarkan prosedur sebagai berikut.

Langkah 1: Menyajikan prosedur.

Menyajikan langkah-langkah atau prosedur menelpon dengan menggunakan bagan arus (flow chart).

Langkah 2: Memberikan bantuan.

Memberi bantuan agar mahasiswa hafal, paham, dan dapat menelpon dengan jalan mendemonstrasikan cara menelpon. 
Langkah 3: Pemberian latihan.

Menugasi mahasiswa untuk mempraktekkan cara menelpon.

Langkah 4: Pemberian umpan balik.

Memberitahukan apakah yang dilakukan oleh mahasiswa dalam praktek sudah betul atau salah. Beri konfirmasi jika betul dan koreksi jika salah.

Langkah 5: Pemberian tes.

Berikan tes dalam bentuk "do it test", artinya mahasiswa disuruh praktek lalu diamati.

7. Strategi mengajarkan/menyampaikan materi aspek afektif.

Termasuk materi pembelajaran aspek sikap (afektif) menurut Bloom (1978) adalah pemberian respons, penerimaan suatu nilai, internalisasi, dan penilaian.

Beberapa strategi mengajarkan materi aspek sikap antara lain: penciptaan kondisi, pemodelan atau contoh, demonstrasi, simulasi, dan penyampaian ajaran.

Contoh: Penciptaan kondisi agar memiliki sikap tertib dalam antrean, di depan loket dipasang jalur untuk antri berupa pagar besi yang hanya dapat dilalui seorang demi seorang secara bergiliran.

Pemodelan atau contoh: Seseorang baik nyata atau fiktif yang perilakunya diidolakan oleh mahasiswa. Misalnya tokoh Bima dalam Mahabarata. Sifat Bima yang gagah berani dapat menjadi idola anak.

B. Strategi mempelajari bahan ajar oleh mahasiswa

Ditinjau dari dosen, perlakuan (treatment) terhadap materi pembelajaran berupa kegiatan dosen menyampaikan atau mengajarkan kepada mahasiswa. Sebaliknya, ditinjau dari segi mahasiswa, perlakuan terhadap materi pembelajaran berupa mempelajari atau berinteraksi dengan materi pembelajaran. Secara khusus dalam mempelajari materi pembelajaran, kegiatan mahasiswa dapat dikelompokkan menjadi empat, yaitu menghafal, menggunakan, menemukan, dan memilih.

Penjelasan dan contoh disajikan sebagai berikut.

1. Menghafal (verbal \& parafrase).

Ada dua jenis menghafal, yaitu menghafal verbal (remember verbatim) dan menghafal parafrase (remember paraphrase). Menghafal verbal adalah menghafal persis seperti apa adanya. Terdapat materi pembelajaran yang memang harus dihafal persis seperti apa adanya, misalnya nama orang, nama tempat, nama zat, lambang, peristiwa sejarah, namanama bagian atau komponen suatu benda, $\mathrm{dsb}$. Sebaliknya ada juga materi pembelajaran yang tidak harus dihafal persis seperti apa adanya tetapi dapat diungkapkan dengan bahasa atau kalimat sendiri (hafal parafrase). Yang penting mahasiswa paham atau mengerti.

2. Menggunakan/mengaplikasikan (Use).

Materi pembelajaran setelah dihafal atau dipahami kemudian digunakan atau diaplikasikan. Jadi dalam proses pembelajaran mahasiswa perlu memiliki kemampuan untuk menggunakan, menerapkan atau mengaplikasikan materi yang telah dipelajari.

Penggunaan fakta atau data adalah untuk dijadikan bukti dalam rangka pengambilan keputusan. Contoh, berdasarkan hasil penggalian ditemukan fakta terdapatnya emas perhiasan yang sudah jadi, setengah jadi, perhiasan yang telah rusak, tungku, dan bahan emas batangan di bekas peninggalan sejarah di desa Wonoboyo Klaten Jawa Tengah. Dengan menggunakan fakta tersebut, ahli sejarah berkesimpulan bahwa lokasi tersebut tempat bekas pengrajin emas.

Penggunaan materi konsep adalah untuk menyusun proposisi, dalil atau rumus. Seperti diketahui, dalil atau rumus merupakan hubungan antara beberapa konsep. Misalnya, dalam berdagang "Jika penjualan lebih besar daripada biaya modal maka akan terjadi laba atau untung". Konsep-konsep dalam jual beli tersebut meliputi penjualan, biaya modal, laba, untung, dan konsep "lebih besar".

Selain itu, penguasaan atas suatu konsep digunakan untuk menggeneralisasi dan membedakan. Contoh, seorang anak yang telah memahami konsep "jam adalah alat penunjuk waktu", akan dapat menggeneralisir bahwa bagaimanapun berbeda-beda bentuk dan ukurannya, dapat menyimpulkan bahwa benda tersebut adalah jam.

Penerapan atau penggunaan prinsip adalah untuk memecahkan masalah pada kasus-kasus lain. Contoh, seorang mahasiswa yang telah mampu menghitung kecepatan reaksi setelah mempelajari rumus kecepatan reaksi, dapat menentukan kecepatan reaksi dimanapun dan berapapun besarnya reaksi yang harus dihitung kecepatannya pada praktek kimia. Seorang mahasiswa yang telah mempelajari cara 
perawatan dan penggunaan media audio visual, maka dapat menerapkannya pada saat perkuliahan dan dimanapun berada.

Penggunaan materi prosedur adalah untuk dikerjakan atau dipraktekkan. Seorang mahasiswa yang telah hafal dan berlatih mengendarai mobil, dapat mengendarai mobil tersebut.

Penggunaan prosedur (psikomotorik) adalah untuk mengerjakan tugas atau melakukan suatu perbuatan. Sebagai contoh, mahasiswa dapat mengendarai mobil setelah menghafal langkahlangkah atau prosedur mengendarai mobil.

Penggunaan materi sikap adalah berperilaku sesuai nilai atau sikap yang telah dipelajari. Misalnya, mahasiswa menghemat air ketika mandi dan mencuci setelah mendapatkan pelajaran tentang pentingnya bersikap hemat.

3. Menemukan.

Yang dimaksudkan penemuan (finding) di sini adalah menemukan cara memecahkan masalah-masalah baru dengan menggunakan fakta, konsep, prinsip, dan prosedur yang telah dipelajari.

Menemukan merupakan hasil tingkat belajar tingkat tinggi. Gagne (1987) menyebutnya sebagai penerapan strategi kognitif. Misalnya, setelah mempelajari hukum bejana berhubungan seorang mahasiswa dapat membuat peralatan penyiram pot gantung menggunakan pipa-pipa paralon.

4. Memilih.

Memilih di sini menyangkut aspek afektif atau sikap. Yang dimaksudkan dengan memilih di sini adalah memilih untuk berbuat atau tidak berbuat sesuatu.

\section{Bentuk Pengemasan Materi Pembelajaran}

Bentuk pengemasan materi pembelajaran sebagai berikut.

A. Buku Teks.

Buku teks pelajaran meliputi buku teks utama dan buku teks pelengkap. Buku teks utama berisi bahanbahan pelajaran suatu bidang studi yang digunakan sebagai buku pokok bagi mahasiswa dan dosen. Buku teks pelengkap adalah buku yang sifatnya membantu atau merupakan tambahan bagi buku teks utama dan digunakan oleh dosen dan mahasiswa.

Setiap buku teks pelajaran memiliki standarstandar tertentu. Standar yang berkaitan dengan aspek materi yang harus ada dalam setiap buku pelajaran.
B. Modul

Yang dimaksud dengan modul adalah suatu unit bahan yang dirancang secara khusus sehingga dapat dipelajari oleh mahasiswa secara mandiri. Merupakan program pembelajaran yang utuh, disusun secara sistematis serta mengacu pada tujuan pembelajaran yang jelas dan terukur.

C. Diktat

Seperti buku namun tidak selengkap buku dan digunakan untuk kalangan sendiri sebagai pendukung buku teks.

D. Lembar Kerja Mahasiswa.

Materi pembelajaran yang menyediakan yang menyediakan aktivitas-aktivitas yang berpusat pada mahasiswa.

E. Hands- out

Sesuatu yang diberikan secara garis besar, gratis.

\section{DAFTAR PUSTAKA}

Abdul G. (1986). Disain instruksional: langkah sistematis penyusunan pola dasar kegiatan belajar mengajar. Sala: Tiga Serangkai.

Abdul G. (1987). Pengaruh strategi urutan penyampaian, umpan balik, dan keterampilan intelektual terhadap hasil belajar konsep. Jakarta : PAU - UT.

Bloom , et al. (1956). Taxonomy of educational objectives: the classification of educational goals. New York: McKay.

Center for Civics Education. (1997). National standard for civics and governement. Calabasas CA: CEC Publ.

Dick, W. \& Carey L. (1978). The systematic desgin of instruction. Illinois: Scott \& Co. Publication.

Direktorat Pendidikan Menengah Umum (2001). Kebijakan pendidikan menengah umum. Jakarta: Direktorat Pendidikan Menengah Umum.

Departemen Pendidikan Nasional, Panduan Pengembangan Materi Pembelajaran SMP, Jakarta : Direktorat Jenderal Manajemen Pendidikan Dasar dan Menengah,Direktorat Pembinaan Sekolah Menengah Pertama.

Edwards, H. C., et. al. (1988). Planning, teaching, and evaluating: a competency approach. Chicago: Nelson-Hall.

Hall, Gene E \& Jones, H.L. (1976). Competency-based education: a process for the improvement of education. New Jersey: Englewood Cliffs, Inc.

Joice, B, \& Weil, M. (1980). Models of teaching. New Jersey: Englewood Cliffs, Publ. 
Kemp, G. (1977). Instructional design: a plan for unit and curriculum development. New Jersey: Sage Publication.

Kaufman, R. A. (1992). Educational systems planning. New Jersey: Englewood Cliffs.

Marzano, R. J. \& Kendal, J. S. (1996). Designing standardbased districs, schools, and classrooms. Virginia: Assiciation for Supervision and Curriculum Development.

McAshan, H. H. (1989). Competency-based education and behavioral objectives. New Jersey: Educational Technology Publications, Engelwood Cliffs.

Oneil Jr. \& Harold, F. (1989). Procedures for instructional systems development. New York: Academic Press.

Reigeluth, C. M. (1987) Instructional theories in action: lessons illustrating selected theories and models. New Jersey: Lawrence Erlbaum Associates Publ.
Russell, J. D. (1984). Modular instruction: a guide to design, selection, utilization and evaluation of modular materials. Minneapolis: Burgess Publishing Company.

\section{KETERANGAN PENULIS}

Dr. Wahyu Sri Ambar Arum, M.A. saat ini menjadi dosen tetap S1 Manajemen Pendidikan FIP UNJ dan pernah menjabat sebagai pembantu dekan III di FIP UNJ. Penulis berpengalaman mengajar di perguruan tinggi di tingkat S1 dan S2 di UNISMA, UHAMKA, dan STISIP Jakarta hingga tahun 2003. Selain mengajar, sampai saat ini aktif dalam kegiatan seminar dan lokakarya terutama dalam bidang pendidikan. Buku terbarunya adalah Manajemen Sarana dan Prasarana Pendidikan yang baru diterbitkan awal tahun 2007. 